\title{
Long noncoding RNA HOTTIP as a novel predictor of lymph node metastasis and survival in human cancer: a systematic review and meta-analysis
}

\author{
Zhicong Chen ${ }^{1, *}$, Anbang He ${ }^{1, *}$, Dailian Wang ${ }^{1}$, Yuchen Liu ${ }^{1}$ and Weiren Huang ${ }^{1}$ \\ ${ }^{1}$ Key Laboratory of Medical Reprogramming Technology, Shenzhen Second People's Hospital, The First Affiliated Hospital of \\ Shenzhen University, Shenzhen, China \\ * These authors have contributed equally to this work \\ Correspondence to: Weiren Huang, email: pony8980@163.com
}

Yuchen Liv, email: liuyuchenmdcg@163.com

Keywords: IncRNA, HOTTIP, cancer, prognosis, lymph node metastasis

Received: July 13,2016 Accepted: October 22, $2016 \quad$ Published: October 28, 2016

\section{ABSTRACT}

HOXA transcript at the distal tip (HOTTIP), a functional IncRNA transcribed from the 5' tip of the HOXA locus, has been functionally characterized as an oncogene in various cancers. To further explore the clinical value of HOTTIP in cancer, we collected all relevant studies and investigated the association between HOTTIP level and lymph node metastasis (LNM) or overall survival (OS). Literature collection was conducted by searching electronic databases PubMed, Cochrane Library, OVID, Web of Science and Chinese National Knowledge Infrastructure (CNKI)(up to July 7, 2016). Seven studies with 652 cancer patients were included in the meta-analysis according to the inclusion and exclusion criteria. The results showed a significant positive association between HOTTIP levels and LNM (Odds ratio, OR = 2.30, $95 \%$ CI: 1.58-3.35, $p<$ $0.0001)$ in a fixed-effects model $\left(I^{2}=0 \%, p=0.949\right)$ and it could also predict poor OS in cancer patients (Hazard ratio HR $=2.24,95 \% \mathrm{CI}: 1.74-2.90, p<0.00001$ ) in a fixed-effects model $\left(\mathrm{I}^{2}=0 \%, p=0.925\right)$. In conclusion, this meta-analysis demonstrated that the higher expression level of HOTTIP is correlated with positive LNM and poor OS in different types of cancer and HOTTIP might serve as a novel predictor of LNM and survival in human cancer.

\section{INTRODUCTION}

\footnotetext{
Nowadays, cancer is still a major public health problem, one leading cause of death all over the world, due to the increasing incidence and mortality. Estimated by GLOB-CAN 2012, there were 14.1 million new cancer cases, 8.2 million cancer deaths, and 32.6 million people living with cancer occurred in 2012 worldwide [1].It is predicted that there will be about 4.3 million newly diagnosed invasive cancer cases and 2.8 million cancer deaths in 2015 in China [2]. There is no doubt that the ideal cancer screening tools are definitely required in predictive, diagnostic and prognostic aspects. Among them, risk assessment and prognostication are indispensable for treatment decision making, patient counseling, and inclusion in clinical trials. Like TNM, a recognized cancer staging notation system, is widely used for adopting a global standard to give an indication
}

of prognosis. However, common staging systems have been performed with limited prediction accuracy because it cannot incorporate novel information such as biomarkers or more complex bioinformatics. More and better prediction tools are needed to fulfill the accuracy and utility of prediction models for cancer.

A notable revolution has been sparked in the oncology field due to the identification and exploration of so many cancer-associated lncRNAs. Numerous evidences suggest that lncRNAs served as critical regulators in the development of different cancers by influencing diverse cellular processes, including cancer initiation and progression $[3,4]$. HOXA transcript at the distal tip (HOTTIP), a lncRNA transcribed from the 5' tip of the HOXA locus and serves as a key locus control element of HOXA genes and distal identity [5], has been recently functionally characterized by its tumor-relativity and involvement in carcinogenesis. Up-regulated expression 
of HOTTIP has been reported in different cancers, including hepatocellular carcinoma [6], pancreatic cancer [7], colorectal cancer [8, 9], osteosarcoma [10], tongue squamous cell carcinoma [11] and gastric cancer [12]. All these data indicated that HOTTIP plays an potential oncogenic role in these tumors by promoting cell proliferation, inhibiting cell apoptosis and increasing cell migration. Together, lncRNA HOTTIP may not only act as a potential therapeutic target, but also as a novel prognostic biomarker in cancer. To shed light on these results and to more precisely evaluate the relationship between lncRNA HOTTIP and lymph node metastasis / survival in human cancer, we performed a meta-analysis of published studies.

\section{RESULTS}

\section{Selection of studies}

A total of 188 records were retrieved from the below databases in initial search and 37 duplicate reports were excluded. After detailed screening of the title and abstract, irrelevant and non-comparative articles were excluded and 16 potential eligible studies were selected. After further evaluation of the full articles, a total of 7 publications addressing the relationship between lncRNA HOTTIP and cancer LNM or OS were found to meet all of the inclusion criteria and used for data extraction. All of the included studies were non-randomized. A flowchart of the study selection process is shown in Figure 1.


Figure 1: Flowchart of selecting studies for inclusion. 


\begin{tabular}{|c|c|c|c|c|c|c|c|c|c|c|c|c|c|c|c|}
\hline \multirow{2}{*}{ Study } & \multirow{2}{*}{ Year } & \multirow{2}{*}{ Country } & \multirow{2}{*}{$\begin{array}{l}\text { Cancer } \\
\text { type }\end{array}$} & \multirow{2}{*}{$\begin{array}{c}\text { Total } \\
\text { number }\end{array}$} & \multirow{2}{*}{$\begin{array}{c}\text { Detection } \\
\text { method }\end{array}$} & \multirow{2}{*}{ Cut-off } & \multicolumn{4}{|c|}{ HOTTIP expression } & \multirow{2}{*}{$\begin{array}{l}\text { Survival } \\
\text { analysis }\end{array}$} & \multirow{2}{*}{$\begin{array}{l}\text { Multivariate } \\
\text { analy sis }\end{array}$} & \multirow{2}{*}{$\begin{array}{c}\mathrm{HR} \\
\text { statistic }\end{array}$} & \multirow{2}{*}{$\begin{array}{c}\text { Hazard } \\
\text { ratios } \\
(95 \% \mathrm{Cl})\end{array}$} & \multirow{2}{*}{$\begin{array}{l}\text { Follow- } \\
\text { up, } \\
\text { moths }\end{array}$} \\
\hline & & & & & & & $\begin{array}{c}\text { High } \\
\text { expression }\end{array}$ & $\begin{array}{l}\text { High } \\
\text { with } \\
\text { LNM }\end{array}$ & $\begin{array}{l}\text { Low } \\
\text { expression }\end{array}$ & $\begin{array}{l}\text { Low } \\
\text { with } \\
\text { LNM }\end{array}$ & & & & & \\
\hline Quagliata & 2014 & Switzer land & $\mathrm{HCC}$ & 52 & RT-qPCR & $\begin{array}{l}\mathrm{R} \propto \mathrm{C} \\
\text { curve }\end{array}$ & 32 & NA & 20 & NA & os & No & $\begin{array}{l}\text { Survival } \\
\text { curve }\end{array}$ & $\begin{array}{c}1.580 \\
(0.67-3.64)\end{array}$ & $\begin{array}{c}80 \\
\text { (total) }\end{array}$ \\
\hline Wang & 2015 & Chine & $\mathrm{PC}$ & 144 & RT-qPCR & $\begin{array}{l}\mathrm{R} \propto \mathrm{C} \\
\text { curve }\end{array}$ & 118 & 75 & 28 & 10 & os & Yes & $\begin{array}{l}\text { Data in } \\
\text { paper }\end{array}$ & $\begin{array}{c}2589 \\
(1.385-4.839)\end{array}$ & $\begin{array}{c}60 \\
\text { (totsl) }\end{array}$ \\
\hline Ren & 2015 & Chine & CRC & 158 & RT-qPCR & Median & 77 & 47 & 79 & 38 & os & Yes & $\begin{array}{l}\text { Data in } \\
\text { paper }\end{array}$ & $\begin{array}{c}2.151(1.308 \\
3.415)\end{array}$ & $\begin{array}{c}48 \\
\text { (median) }\end{array}$ \\
\hline نا & 2015 & Chine & $\operatorname{cs} A$ & 68 & RT-qPCR & Median & 34 & NA & 34 & NA & os & Yes & $\begin{array}{l}\text { Data in } \\
\text { paper }\end{array}$ & $\begin{array}{c}2.887(1.387- \\
7.061)\end{array}$ & $\begin{array}{c}60 \\
\text { (totsl) }\end{array}$ \\
\hline Zhang & 2015 & Ching & TSCC & 86 & RT-qPCR & Median & 44 & 28 & 42 & 18 & os & Yes & $\begin{array}{l}\text { Data in } \\
\text { paper }\end{array}$ & $\begin{array}{c}2.113 \\
(1.082-3.115)\end{array}$ & $\begin{array}{c}38 \\
\text { (median) }\end{array}$ \\
\hline Lian & 2018 & Chine & CRC & 48 & $R T-q P C R$ & $\begin{array}{c}\text { X-tile } \\
\text { algorithm }\end{array}$ & 32 & 21 & 16 & 7 & NA & NA & NA & NA & NA \\
\hline$Y e$ & 2016 & Chine & GC & 98 & $R T-q P C R$ & Median & 49 & 39 & 49 & 29 & os & Yes & $\begin{array}{l}\text { Survival } \\
\text { curve }\end{array}$ & $\begin{array}{c}2.420 \\
(1.21-4.85)\end{array}$ & $\begin{array}{c}60 \\
\text { (total) }\end{array}$ \\
\hline
\end{tabular}

HCC hepatocellular carcinoma, PC pancreatic cancer, CRC colorectal cancer, OSA osteosarcoma, TSCC tongue squamous cell carcinoma, GC gastric cancer, RT-qPCR real-time quantitative PCR, LNM lymph node metastasis, OS overall survival, NA not available.

Table 2: Methodological quality of the eligible studies according to the Newcastle-Ottawa scale

\begin{tabular}{|c|c|c|c|c|c|c|c|c|c|}
\hline Author/year & Country & $\begin{array}{c}\text { Adequacy of } \\
\text { case } \\
\text { definition }\end{array}$ & $\begin{array}{c}\text { Representativeness } \\
\text { of the cases }\end{array}$ & $\begin{array}{l}\text { Selection } \\
\text { of controls }\end{array}$ & $\begin{array}{c}\text { Definition of } \\
\text { controls }\end{array}$ & $\begin{array}{l}\text { Comparability } \\
\text { cases/controls }\end{array}$ & $\begin{array}{l}\text { Ascertainment } \\
\text { of exposure }\end{array}$ & $\begin{array}{c}\text { Same method of } \\
\text { ascertainment }\end{array}$ & $\begin{array}{l}\text { Nonreponse } \\
\text { rate }\end{array}$ \\
\hline Quagliata & Switzerland & $\star$ & $\star$ & $\star$ & NA & $\star \star$ & $\star$ & $\star$ & NA \\
\hline Wang & China & $\star$ & $\star$ & $\star$ & NA & $\star \star$ & $\star$ & $\star$ & NA \\
\hline Ren & China & $\star$ & $\star$ & $\star$ & NA & $\star \star$ & $\star$ & $\star$ & NA \\
\hline $\mathrm{Li}$ & China & $\star$ & $\star$ & $\star$ & NA & $\star \star$ & $\star$ & $\star$ & NA \\
\hline Zhang & China & $\star$ & $\star$ & $\star$ & $\mathrm{NA}$ & $\star \star$ & $\star$ & $\star$ & NA \\
\hline Lian & China & $\star$ & $\star$ & $\star$ & NA & $\star \star$ & $\star$ & $\star$ & NA \\
\hline Ye & China & $\star$ & $\star$ & $\star$ & NA & $\star \star$ & $\star$ & $\star$ & NA \\
\hline
\end{tabular}

Notes: This table identifies "high-quality" choices with a "star $(*)$ ". A study can be awarded a maximum of one star for each numbered item within the selection and exposure categories. A maximum of two stars can be given for comparability. NA: not available

\section{Characteristics of eligible studies}

All of the eligible studies were published recently (2014-2016). These studies included a total of 652 patients with a mean patient sample size of $N=93.14$ (range 48 to 156). Six different types of cancer were evaluated in this meta-analysis: 2 colorectal cancers (CRC), 1 hepatocellular carcinoma (HCC), 1 pancreatic cancer(PC), 1 osteosarcoma(OSA), 1tongue squamous cell carcinoma(TSCC), and 1 gastric cancer (GC). All the detected samples were tissues or frozen tissues from the patients without anti-cancer treatments. The expression of HOTTIP was measured by RT-qPCR and normalized to GAPDH or $\beta$-action. Cut-off scores that discriminate between high and low HOTTIP were selected by ROC curve or median value or X-tile algorithm. Of the 7 included studies, not all studies examined both OS and LNM. All the diagnoses of lymph node metastasis were based on pathology. The main characteristics of the eligible studies were summarized in Table-1. The Newcastle-Ottawa Scale (NOS) confirmed that all the studies were of good quality Table-2.

\section{Meta-analysis results}

\section{Association between IncRNA HOTTIP and LNM}

Five studies reporting a total of 444 patients with LNM were included based on different HOTTIP expression patterns. The fixed-effects model was adopted as the nonsignificant heterogeneity $\left(\mathrm{I}^{2}=0 \%, p=0.95\right)$. Analysis showed the OR of 2.30 with $95 \%$ CI: 1.58 $3.35(p<0.0001)$, which revealed that a higher HOTTIP expression was predictive of higher LNM (Figure 2). The result demonstrated that cancer patients with high HOTTIP expression in tumor tissues were more susceptibility to develop LNM. 




Figure 2: Forest plot of the correlation between HOTTIP expression levels and LNM in different cancer patients

Study

ID
$\mathrm{HR}(95 \% \mathrm{Cl})$

Weight

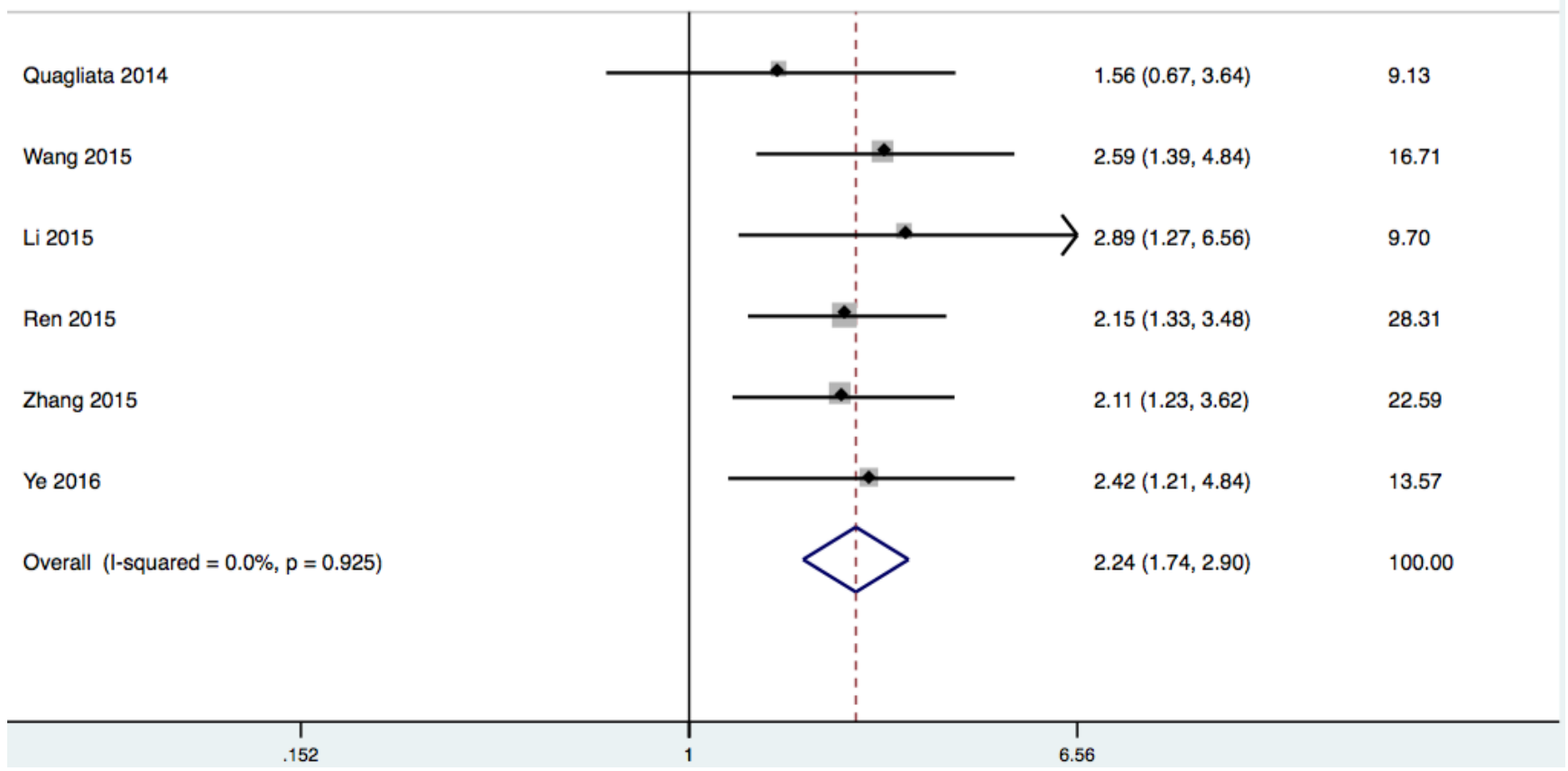

Figure 3: Forest plot of the correlation between HOTTIP expression levels and OS in different cancer patients 


\section{Association between IncRNA HOTTIP and OS}

Six studies reporting a total of 604 patients with OS were included based on different HOTTIP expression levels. The relationship between HOTTIP expression and the OS of cancer patients was found to be of no significant heterogeneity $\left(\mathrm{I}^{2}=0 \%, P=0.92\right)$, and the fixed-effect model was therefore applied. Data of pooled HRs (HR $=2.24,95 \%$ CI: 1.74-2.90, $P<0.00001)$ manifested that high expression of HOTTIP had a statistic shorter OS (Figure 3). In other words, high HOTTIP expression correlated with a worse survival.

\section{Publication bias}

Egger's tests were performed to assess publication bias of the present meta-analysis. In both LNM group (Egger's test, $t=1.77, p=0.176$ ) and OS group (Egger's test, $t=0.11, p=0.918)$, no significant publication bias was observed by the Egger's test (Figure 4).

\section{DISCUSSION}

Since the completion of the ENCODE project, the noncoding RNAs have captured our great attention. LncRNAs, defined as non-coding transcripts surpass 200 nucleotides in length, have been indeed revealed in various aspects of cellular homeostasis in different cancers. Increasing tumor-associated lncRNAs have been functionally characterized and totally expanded cancer perspective. Meanwhile, accumulating evidences suggested that cancer-specific lncRNAs might serve as novel prognostic molecular markers [13-15]. Therefore, the comprehensive identification of cancer-associated lncRNAs may provide a groundbreaking method to more precisely evaluate the prognosis of different cancers.

HOTTIP is a well-known lncRNA which acts as a master regulator of HOXA genes. Recently, the involvement of the lncRNA HOTTIP in various cancers
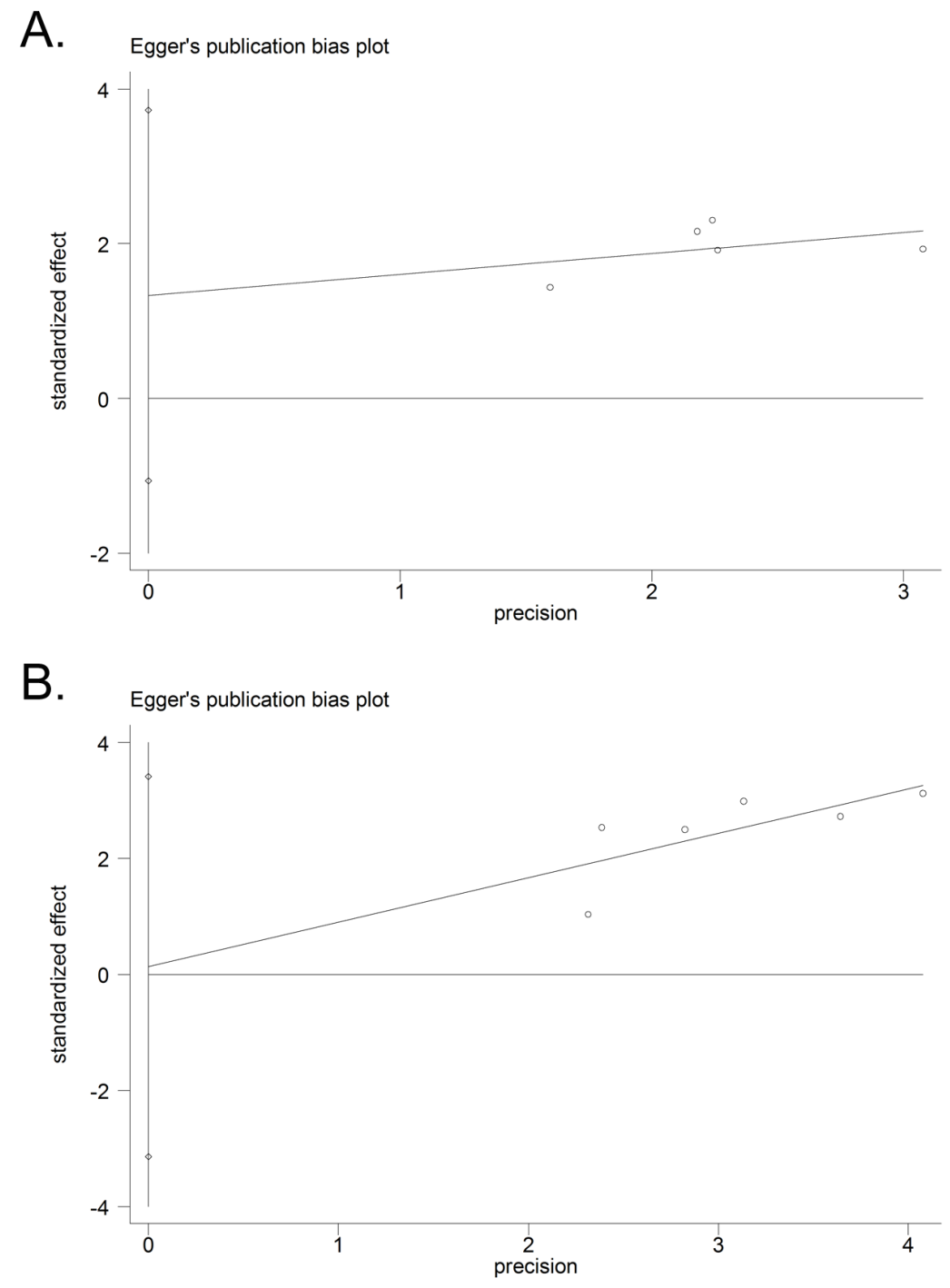

Figure 4: Funnel plot analysis of potential publication bias in LNM and OS group(Egger's test): A. LNM group; B. OS group. 
has been elucidated [6-12]. The further comprehensive mechanism between HOTTIP and cancer was reported in continuance. HoxA13-HOTTIP-IGFBP-3 cascade is critical for the carcinogenic characteristics in human gastric cancer [16]. HOTTIP plays a pivotal role in osteosarcoma cell initiation and chemoresistance via activating $\mathrm{Wnt} / \beta$-catenin signaling pathway [17]. Further exploration of correlation between HOTTIP and cancer is definitely required.

In order to combine the results of previous studies about HOTTIP and cancer to arrive at a summary conclusion, we elucidated the relationships between HOTTIP expression levels and LNM and OS in cancer in the present meta-analysis. To the best of our knowledge, this is the first meta-analysis providing comprehensive insights into the correlation of IncRNA HOTTIP and cancer prognosis. The pooled data of eligible studies indicated that high HOTTIP expression was significant correlated with LNM $(\mathrm{OR}=2.30,95 \% \mathrm{CI}: 1.58-3.35$, $p<0.0001$ ), and OS (HR $=2.24,95 \% \mathrm{CI}: 1.74-2.90, p$ $<0.00001)$. High expression of HOTTIP predicted more prone to LNM and poor OS. Although HOTTIP was found to be significantly associated with the prognosis of cancer patients, some limitations in our meta-analysis should be mentioned. First and foremost, the eligible studies in this analysis were insufficient. Only seven studies and six types of cancer were included. Potential publication bias is likely to exist, in spite of no evidence obtained from our analysis. Due to inadequate data, we did not evaluate sensitivity bias. Additionally, most of the studies were conducted with Chinese sample populations and, consequently, our results may result in potential ethnic bias and only applicable in this ethnic group. What's more, the cut-off value of HOTTIP expression differed in these studies. Last but not least, many factors, such as treatment, and duration of follow- up, may also affect OS. Hence, the data of this meta-analysis should be updated and confirmed by following studies.

In conclusion, despite the limitations described above, our systematic review and meta-analysis reveals that LncRNA HOTTIP is significantly associated with LNM and OS in patients with diverse cancers, and could be used as a potentially and promising prognostic marker in human cancer. Nevertheless, large-volume, welldesigned studies with extensive follow-up are awaited to confirm and update the findings of this analysis.

\section{MATERIALS AND METHODS}

\section{Search strategy}

A literature search was performed on PubMed, Cochrane Library, OVID, Web of Science and Chinese National Knowledge Infrastructure (CNKI) using the following search keyword: HOTTIP or HOXA transcript at the distal tips. The last update of searching time was July 7, 2016.

\section{Inclusion and exclusion criteria}

Inclusion criteria are as the following: (1) Article investigating the association between HOTTIP expression and prognosis of patients cancer; (2) Cancer patients were grouped according to the expression levels of HOTTIP which were measured in primary tumor tissues; (3) Related clinical parameters were described, including LNM or OS; (5) Sufficient data were contained for the computation of OR, HR and corresponding $95 \%$ CI. Exclusion criteria are as the following: (1) Duplicate publications; (2) Letters, editorials, expert opinions, case reports and reviews; (3) Irrelevant or non-comparative or nonhuman research; (4) Studies without usable data.

\section{Date extraction}

Data were extracted independently by three authors ( $\mathrm{CZC}, \mathrm{HAB}$, and WDL), according to the inclusion and exclusion criteria. Disagreements were resolved by two investigators (LYC,HWR) by discussions. The following data were extracted: (1) Publication information: first author's last name, year of publication, country; (2) Patients' characteristics: cancer type; number of participants, detected sample and follow-up duration;

(3) HOTTIP expression measurement and cut-off value;

(4) ORs of HOTTIP for LNM: number of patients with LNM in each group; (5) HRs of HOTTIP for OS as well as their 95\% CIs and P values. If only Kaplan-Meier curves were available, we extracted data from the graphical survival plots and estimated the HRs. All the calculations mentioned above were based on the methods illustrated by Parmar et al. [18] and Tierney et al. [19]

\section{Statistical methods}

A test of heterogeneity of combined ORs or HRs was conducted using Cochran's Q test and Higgins I-squared statistic. $P$ values $<0.1$ was considered significant. $\mathrm{I}^{2}$ values $>50 \%$ indicate heterogeneity among studies. A fixed effect model was applied when heterogeneity might not be important between studies $(P>0.1)$, while the random effect model was used if heterogeneity was observed $(P$ $<0.1)$. The potential publication bias was assessed by the Egger's test. All the statistical analyses were carried out by using the Stata 12.0. $P$ values $<0.05$ were considered statistically significant. 


\section{ACKNOWLEDGMENTS}

We are indebted to the donors whose names were not included in the author list, but who participated in this program. This work was supported by the National Natural Science Foundation of China(81402103), International S\&T Cooperation program of China (ISTCP) (2014DFA31050), The National Science Foundation Projects of Guangdong Province (2014A030313717), the Shenzhen Municipal Government of China (ZDSYS201504301722174, JCYJ20150330102720130, GJHZ20150316154912494), and Special Support Funds of Shenzhen for Introduced High-Level Medical Team.

\section{CONFLICTS OF INTEREST} interests.

All authors declare that there is no conflict of

\section{REFERENCES}

1. Ferlay J, Soerjomataram I, Dikshit R, Eser S, Mathers C, Rebelo M, Parkin DM, Forman D and Bray F. Cancer incidence and mortality worldwide: sources, methods and major patterns in GLOBOCAN 2012. Int J Cancer. 2015; 136:E359-386.

2. Chen W, Zheng R, Baade PD, Zhang S, Zeng H, Bray F, Jemal A, Yu XQ and He J. Cancer statistics in China, 2015. CA Cancer J Clin. 2016.

3. Schmitt AM and Chang HY. Long Noncoding RNAs in Cancer Pathways. Cancer Cell. 2016; 29:452-463.

4. Huarte M. The emerging role of lncRNAs in cancer. Nat Med. 2015; 21:1253-1261.

5. Wang KC, Yang YW, Liu B, Sanyal A, Corces-Zimmerman R, Chen Y, Lajoie BR, Protacio A, Flynn RA, Gupta RA, Wysocka J, Lei M, Dekker J, Helms JA and Chang HY. A long noncoding RNA maintains active chromatin to coordinate homeotic gene expression. Nature. 2011; 472:120-124.

6. Quagliata L, Matter MS, Piscuoglio S, Arabi L, Ruiz C, Procino A, Kovac M, Moretti F, Makowska Z, Boldanova T, Andersen JB, Hammerle M, Tornillo L, et al. Long noncoding RNA HOTTIP/HOXA13 expression is associated with disease progression and predicts outcome in hepatocellular carcinoma patients. Hepatology. 2014; 59:911-923.

7. Wang YX, Li ZH, Zheng SY, Zhou Y, Zhao L, Ye HL, Zhao XH, Gao WC, Fu ZQ, Zhou QB and Liu YM. Expression pro le of long non-coding RNAs in pancreatic cancer and their clinical signi cance as biomarkers. Oncotarget. 2015;6:35684-98. doi: 10.18632/oncotarget.5533.

8. Ren YK, Xiao Y, Wan XB, Zhao YZ, Li J, Li Y, Han GS, Chen XB, Zou QY, Wang GC, Lu CM, Xu YC and Wang YC. Association of long non-coding RNA HOTTIP with progression and prognosis in colorectal cancer. Int $\mathrm{J}$ Clin Exp Pathol. 2015; 8:11458-11463.

9. Lian Y, Ding J, Zhang Z, Shi Y, Zhu Y, Li J, Peng P, Wang $J$, Fan $Y$, De $W$ and Wang $K$. The long noncoding RNA HOXA transcript at the distal tip promotes colorectal cancer growth partially via silencing of $\mathrm{p} 21$ expression. Tumour Biol. 2016; 37:7431-7440.

10. Li F, Cao L, Hang DH, Wang F and Wang QG. Long noncoding RNA HOTTIP is up-regulated and associated with poor prognosis in patients with osteosarcoma. Int J Clin Exp Pathol. 2015; 8:11414-11420

11. Zhang H, Zhao L, Wang YX, Xi M, Liu SL and Luo LL. Long non-coding RNA HOTTIP is correlated with progression and prognosis in tongue squamous cell carcinoma. Tumour Biol. 2015; 36:8805-8809.

12. Ye H, Liu K and Qian K. Overexpression of long noncoding RNA HOTTIP promotes tumor invasion and predicts poor prognosis in gastric cancer. Onco Targets Ther. 2016; 9:2081-2088.

13. Hong HH, Hou LK, Pan X, Wu CY, Huang H, Li B and Nie W. Long non-coding RNA UCA1 is a predictive biomarker of cancer. Oncotarget. 2016; 7:44442-44447. doi: 10.18632/ oncotarget.10142.

14. Cui Z, Chen Y, Xiao Z, Hu M, Lin Y, Chen Y and Zheng $\mathrm{Y}$. Long noncoding RNAs as auxiliary biomarkers for gastric cancer screening: A pooled analysis of individual studies. Oncotarget. 2016;7:25791-800. doi: 10.18632/ oncotarget.8268.

15. Shen Y, Katsaros D, Loo LW, Hernandez BY, Chong C, Canuto EM, Biglia N, Lu L, Risch H, Chu WM and Yu H. Prognostic and predictive values of long non-coding RNA LINC00472 in breast cancer. Oncotarget. 2015; 6: 85798592. doi: 10.18632/oncotarget.3287.

16. Wang SS, Wuputra K, Liu CJ, Lin YC, Chen YT, Chai CY, Lin CS, Kuo KK, Tsai MH, Wang SW, Chen KK, Miyoshi $\mathrm{H}$, Nakamura $Y$, et al. Oncogenic function of the homeobox A13-long noncoding RNA HOTTIP-insulin growth factorbinding protein 3 axis in human gastric cancer. Oncotarget. 2016;7:36049-36064. doi: 10.18632/oncotarget.9102.

17. Li Z, Zhao L and Wang Q. Overexpression of long noncoding RNA HOTTIP increases chemoresistance of osteosarcoma cell by activating the Wnt/beta-catenin pathway. Am J Transl Res. 2016; 8:2385-2393.

18. Parmar MK, Torri V and Stewart L. Extracting summary statistics to perform meta-analyses of the published literature for survival endpoints. Statistics in medicine. 1998; 17:2815-2834.

19. Tierney JF, Stewart LA, Ghersi D, Burdett S and Sydes MR. Practical methods for incorporating summary time-toevent data into meta-analysis. Trials. 2007; 8:16. 